\title{
Fenomena Overheating Perekonomian Indonesia
}

\author{
Wihana Kirana Jaya
}

Pendahuluan

erjadinya overheated economy, 1 secara sederhana dapat dijelaskan sebagai suatu fenomena, dimana pendapatan nasional riil lebih tinggi daripada pendapatan nasional potensial, dan permintaan agregat akan selalu naik yang tidak diimbangi oleh output potensial. Memanasnya suhu perekonomian ditandai adanya kecenderungan meningkatnya harga-harga umum terutama komoditaskomoditas-strategis. Akibat yang ditimbulkan dari overheated economy ini memberikan signal tingkat inflasi yang tinggi, cepatnya pertumbuhan permintaan domestik masyarakat jika dibandingkan dengan penawaran , meningkatnya jumlah uang beredar, perkembangan kredit yang cukup tinggi khususnya untuk kredit yang mempunyai spekulasi tinggi seperti kredit di sektor properti dan konsumsi, defisit transaksi berjalan yang semakin besar sebagai akibat selalu meningkatnya impor jika dibandingkan dengan ekspor terutama untuk barang-barang konsumsi.

Kuatnya permintaan dalam negeri, menimbulkan dampak meningkatnya kebutuhan yang tercermin pada laju pertumbuhan likuiditas perekonomian (M2) yang cukup tinggi bila dibandingkan dengan M1 (uang kartal dan uang giral).
Penyaluran kredit yang ekpansif di satu sisi dan kurangnya kontrol terhadap penggunaan/alokasi kredit secara-tepat pada sisi lain menupakan penyebab utama terjadinya kredit macet, karena sering terjadi kredit tersebut tidak digunakan seperti pada proposal yang diajukan -sering hanya untuk kebutuhan konsumsiyang berakhir pada kecenderungan meningkatnya permintaan barang yang tidak diikuti oleh penawarannya.

\section{Konsep dan Landasan Teoritis}

Secara teori, pertumbuhan ekonomi yang tinggi akan meningkatkan konsumsi baik oleh pemerintah maupun swasta karena pertumbuhan ekonomi juga mempengaruhi tingkat pendapatan baik perseorangan/swasta maupun pemerintah. Pertumbuhan tingkat konsumsi yang tinggi pada gilirannya akan mendongkrak tingkat inflasi, jika permintaan agregat (aggregate demand) tidak dapat diimbangi oleh penawaran agregat (aggregate supply). Inflasi yang disebabkan oleh kelebihan permintaan ini disebut demand inflation. Untuk melihat fenomena overheating dapat dikaji melalui analisis dasar permintaan dan penawaran agregat seperti pada diagram bagan alur sebagai berikut: 


\section{Gambar 1 : Bagan Alur Overheating Economy}

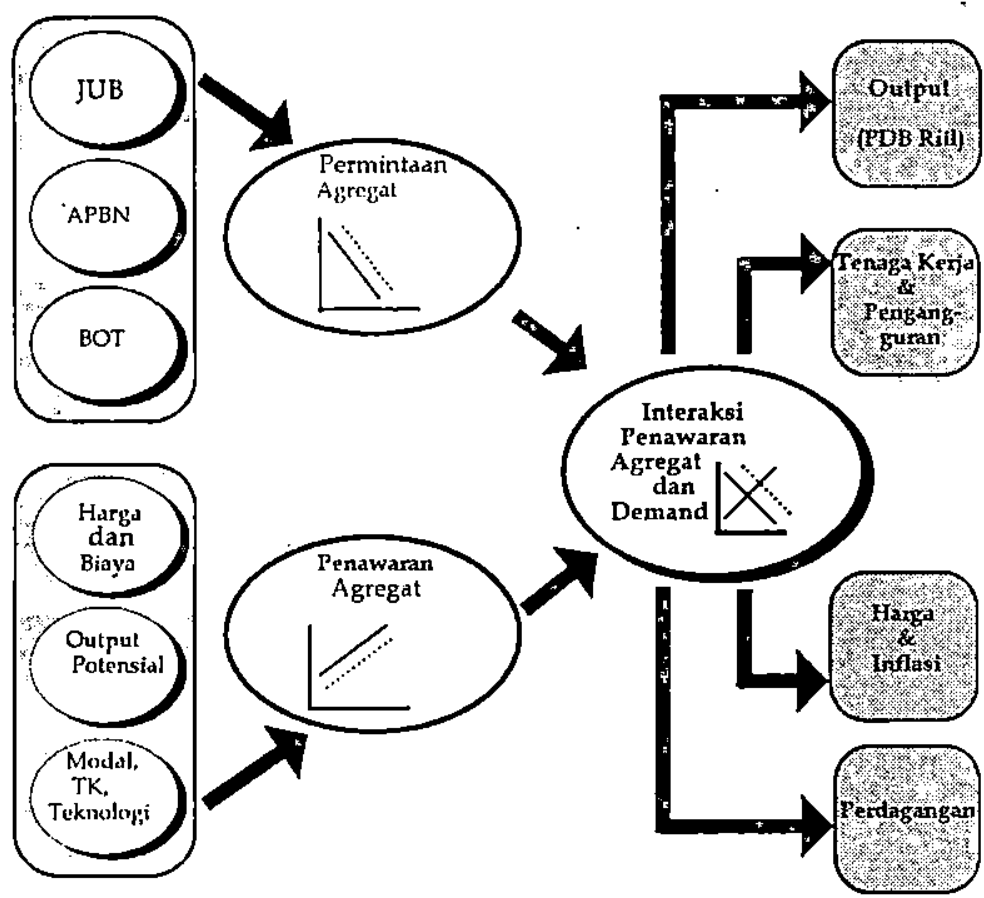

Pada diagram di atas ditunjukkan faktor-faktor utama yang berperan pada aktivitas perekonomian pada umumnya. Sisi kiri merupakan variabel-variabel yang menentukan penawaran dan permintaan agregat, variabel kebijakan seperti kebijakan moneter dan fiskal sampai dengan stok kapital dan tenaga kerja. Bagian tengah diagram merupakan interaksi antara kurva penawaran dengan permintaan agregrat.

Penawaran agregat dipengaruhi oleh tingkat harga, kapasitas produksi dan tingkat biaya yang harus dikeluarkan untuk memproduksi setiap barang. Permintaan agregat menunjukkan jumlah total pengeluaran dari para pelaku ekonomi, baik dari rumah tangga, perusahaan, pemerintah yang tergantung juga pada tingkat harga, kebijakan moneter dan fiskal serta kebijakan lainnya.
Secara grafik, overheating dapat dijelaskan sebagai berikut:

\section{Gambar 2 : Overheating Economy}

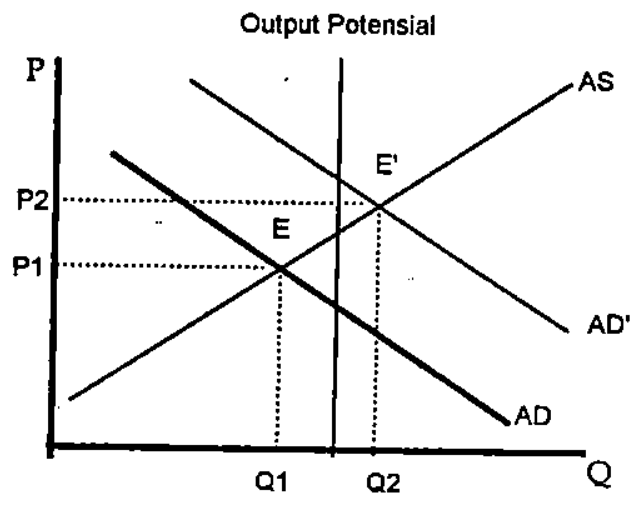


Di sektor moneter, inflasi disebabkan karena JUB yang melimpah di masyarakat. Sehingga untuk menununkan tingkat inflasi dapat dilakukan dengan 'mengurangi jumlah uang yang beredar (JUB). Tetapi pengurangan JUB ini akan menaikkan tingkat bunga/r. Tingkat $r$ yang menaik ini akan menarik dana yang ada di masyarakat ke bank dan jumlah uang beredar akan turun. Suku bunga dalam negeri yang tinggi juga akan membuat kompetitif dengan tingkat suku bunga di luar negeri, dengan demikian akan menjaga arus modal masuk yang sekaligus dapat digunakan untuk menutup kas devisa yang defișit. Kenaikan suku bunga yang cenderung meningkat ini akan mengakibatkan perekonomian yang memanas.

Di samping itu, kebijakan di sektor moneter ini perlu juga ditunjang kebijakan di sektor fiskal. Upaya peningkatan penerimaan pajak, secara tidak langsung akan mempenganuhi likuiditas masyarakat. Dengan demikian jka kedua kebijakan ini akan ditempuh dan ditmbangi dengan kebijakan di sektor riil berupa penyediaan barang kebutuhan konsumsi yang cukup. maka penyakit inflasi yang biasa muncul "mendampingi" pertumbuhan ekonomi yang tinggi dapat dicegah.

Studi empiris kurva Philip juga menjelaskan bahwa inflasi akan cendenung mengikuti kenaikan aktivitas riil. Teori Keynes tentang kurva Philip menjelaskan bahwa obsesi ini adalah reaksi ke dalam disequilibrium dalam bentuk gap GNP yang positif. Hasilriya menunjukkan bahwa hasil kegiatan ekonomi yang meningkat menyebabkan gejala inflasi.

Perubahan kurs juga berpenganh pada gejala overheating. Adanya perbedaan kurs internasional akan berakibat pada penubahan harga barangbarang yang diimport yang pada akhirnya berpengaruh pada defisit atau surplus transaksi berjalan, dan perekonomian akan memanas jika terjadi defisit pada traasaksi berjalan. Kebijakan-kebijakan makro ekonomi yang merubah kurva IS dan LM (pasar barang dan pasar uang), akan merubah Aggregate Demand dan Aggregate Supply.

Keadaan yang sebaliknya adalah kondisi perekonomian yang mendingin (overcooled), di mana perekonomian ditandai dengan tingkat penawaran yang cukup tinggi/naik tetapi tidak diikuti oleh tingkat permintaan yang cukup tinggi pula/ tetap (aggregate supply lebih besar daripada aggregate demand). Overcooled dapat juga dijelaskan dengan adanya penurunan permintaan dimana penawarannya tidak berubah. Secara grafis kedua skenario overcooled ini dapat digambarkan sebagai berikut:

\section{Gambar 3 : Overcooled Economy}
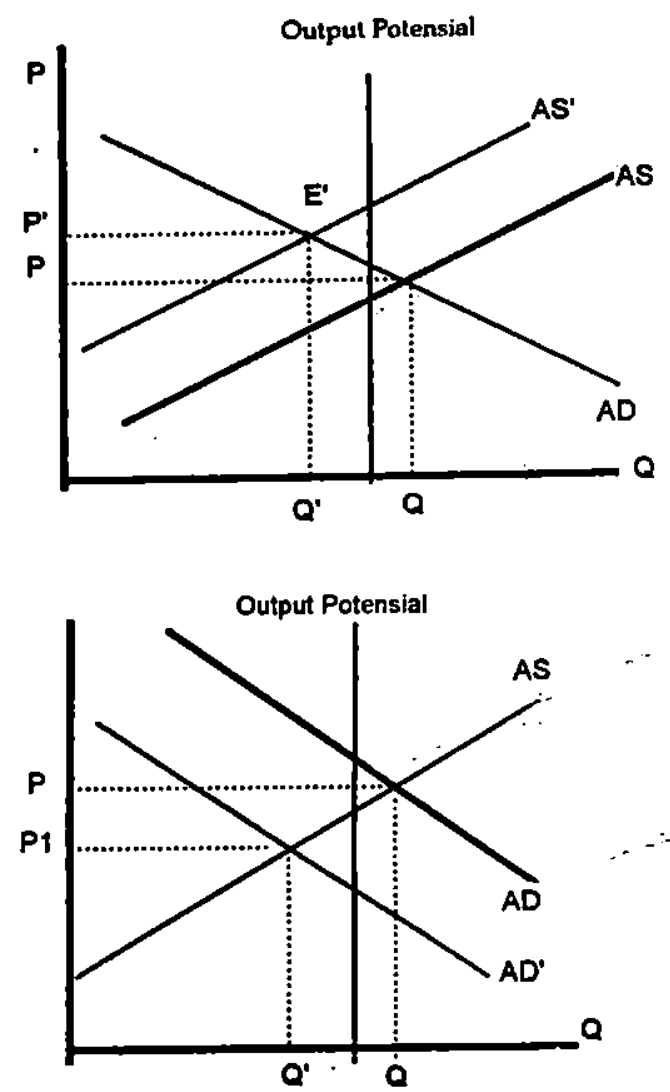
Perekonomian yang mengalami overcooled ini dapat menyebabkan pengangguran, karena adanya kelebihan penawaran output padahal tidak ada yang akan membeli output tersebut.

\section{Fenomena Overheating dl Indonesla}

Saat ini perekonomian Indonesia ditandai oleh beberapa hal yang menunjukkan terjadinya overheated, yaitu tingginya tingkat bunga dan tingginya tingkat inflasi. Walaupun sampai dengan akhir tahun 1995 banyak pengamat ekonomi memperkirakan bahwa pada tahun 1996 tingkat bunga secara perlahan akan menurun, mengikuti penurunan suku bunga di negara-negara maju terutama Amerika. Serikat dan Jepang. Tetapi kenyataannya jauh dari harapan tingkat bunga selama 1995 ternyata lebih tinggi dari tahun 1994 dan sampai dengan akhir tahun 1995 lalu belum tampak tanda-tanda penurunan, sehingga kondisi perekonomian Indonesia sampai dengan akhir tahun 1996 inipun masih cenderung memanas.

Menurut Kadhim A. Al-Eyd (Senior Resident IMF), dikatakan bahwa pertumbuhan ekonomi Indonesia yang tinggi akan berkesinambungan jika tingkat tabungan dalam negeri bisa lebih dipacu. Hal ini dikarenakan pertumbuhan ekonomi yang tinggi akan menaikkan kurva permintaan (aggregate demand), sebagai akibat meningkatnya konsumsi. masyarakat dan pemerintah, perusahaan, dan surplus neraca perdagangan. Meningkatnya permintaan masyarakat ini pada gilirannya akan mengakibatkan peningkatan jumlah uang beredar dan selanjutnya akan mendongkrak tingkat inflasi.

Kalau dirunut ke belakang, over: heating atau memanasnya perekonomian Indonesia berawal pada tahun 1990 sebagai akibat dari Pakto 1988 yakni deregulasi dalam bidang keuangan, moneter dan perbankan yang intinya meningkatkan persaingan sesama bank dalam pengerahan dan pelayanan berbagai kebutuhan masyarakat dan kebijakan dalam menentukan devisa.

Kemudahan dalam perluasan jaringan dan pendirian bank baru mengakibatkan posisi dana yang dihimpun perbankan meningkat dari Rp. 35,7 trilliun pada tahun 1988 menjadi Rp. 54,5 trilliun pada tahun 1989. Selain itu, RR pun diturunkan dari $15 \%$ menjadi $2 \%$. Hal ini mengakibatkan peningkatan dana yang sangat nyata. Akibatnya posisi kredit perbankan naik dari Rp. 44 trilliun pada tahun 1988 dan meningkat menjadi Rp. 63,6 trilliun pada tahun 1989. Gejala ini terus meningkat dengan laju pertumbuhan yang sangat besar.

Besarnya pemberian kredit terutama untuk kredit yang bersifat konsumtif menambah jumlah uang beredar dalam masyarakat dengan cepat, yang pada akhirnya akan mendorong tingkat inflasi. Kita tahu bahwa fenomena inflasi adalah merupakan terlalu banyaknya jumlah uang beredar (JUB) dibandingkan dengan kesediaan masyarakat untuk memegang uang tersebut (excess demand for goods lebih besar dari pada excess supply of money). Kondisi-kondisi yang disebutkan di atas mengakibatkan terjadinya overheating.

Sebagai upaya untuk mengatasi suhu perekonomian pada waktu itu, pemerintah melakukan gebrakan pengetatan kredit. Gebrakan ini dikenal dengan "Gebrakan Sumarlin" yang intinya adalah pengurangan atau pengetatan uang yang beredar (Tight Money Policy/ TMP). Pada waktu itu Prof. Dr. JB Sumarlin mengintruksikan bank-bank umum milik pemerintah untuk membekukan deposito milik beberapa BUMN yang jumlahnya Rp. 1,4 trilyun. Sementara itu Gubernur Bank Indonesia Dr. Arifin Siregar pada saat itu, mengikuti langkah tersebut dengan menetapkan kebijakan pendukung, "operasi pasar terbuka" (open market operation). Dalam hal ini BI mewajibkan bankbank umum (milik pemerintah dan swasta) 
untuk segera menyeimbangkan neraca SBI (Sertifikat Bank Indonesia) dan SBPU (Surat Berharga Pasar Uang)-nya.

Pada waktu itu neraca tersebut tidak menunjukkan keseimbangan, dengan kecenderungan jumlah SBPU yang terlalu besar. Dengan kata lain, sebelum turunnya 'SK "Gebrakan Sumarlin", kebijakan Bank Sentral terlalu ekspansif (ekspansi moneter lebih menonjol), sehingga telah mengakibatkan jumlah uang yang beredar terlalu banyak. Karena itu $\mathrm{Bl}$ berusaha "mengembalikan" SBPU kepada bankbank umum, dan meminta kembali uanguangnya yang "dipinjam" bank-bank umum (Tony Prasetiantono, 1990).

Di lihat dari sisi pertumbuhan perekonomiannya dari tahun 1994 sampai dengan 1996, Indonesia memiliki tingkat pertumbuhan relatif konstan dan cukup tinggi, yaitu sebesar 7,3 pada tahun 1994 dan 7,0 pada tahun 1996 (lihat tabel 1) jika dibandingkan dengan Filipina dan Vietnam.

Jumlah uang beredar dalam arti sempit (M1) hingga Agustus 1995 sebesar Rp. 48.381 trilliun, naik 8,52 dibanding bulan Januari. Sedangkan jumlah uang beredar dalam arti luas (M2) naik dari Rp. 176.227 trilliun menjadi Rp. 202.085 trilliun (tabel 3).

Melihat jumlah uang beredar ( $M 1$ dan M2) semakin meningkat tersebut, maka pemerintah mengambil kebijakan untuk mengurangi JUB tersebut. Ada dua sumber pertumbuhan uang beredar, yaitu net foreign assetdan net domestic assets. Karena net foreign assets pertumbuhannya lebih tidak terkontrol dibandingkan dengan net domestic assets (sebagian besar berasal dari kredit perbankan) maka pemerintah berusaha mengerem laju pertumbuhan uang beredar tersebut dengan mengendalikan ekspansi kredit oleh perbankan.

Kebijakan pemerintah tersebut, dilakukan dengan menggunakan instrumen yang mempengaruhi money multiplier (Boediono 1995). Salah satu instrumen tersebut adalah cash-ratio atau reserve requirement (RR). Dengan menaikkan RR ini maka jumlah uang beredar akan berkurang, sehingga diharapkan laju pertumbuhan ekonomi bisa terkendali.

Selain kebijakan tersebut diatas, pemerintah telah membatasi ekspansi kredit sebesar $16 \%$ untuk tahun 1996/97. Hal ini dikarenakan peranan sektor perbankan terhadap pertumbuhan ekonomi umumnya dianggap cukup besar bahkan sebesar sepertiganya (Muchlis Harun, 1996).

Laju inflasi secara kumulatif pada tahun 1994 sebesar 9,3 persen dan pada tahun 1996 sebesar 7,4 persen (tabel 4). Laju inflasi yang tinggi tersebut disebabkan oleh munculnya gangguan pada pasokan bahan-bahan makanan, di samping kuatnya permintaan domestik, khususnya kegiatan investasi pada sektor-sektor yang terkait dengan kegiatan kontruksi dan perumahan. Selain itu dampak apresiasi Yen terhadap kenaikan harga barangbarang impor ikut mendorong kenaikan laju inflasi dalam negeri secara berarti.

Dampak dari laju inflasi yang cukup tinggi ini adalah menyebabkan barangbarang dalam negeri menjadi kurang dapat bersaing di pasaran internasional. Akibatnya terjadi impor barang konsumsi secara berlebihan yang mengibas pada pembesaran defisit transaksi berjalan. Di samping kenaikan harga di pasar internasional, kenaikan beberapa barang dan jasa impor juga didorong oleh adanya depresiasi rupiah terhadap Yen Jepang yang cukup tinggi (17,6 persen tahun 1994/ 95). Mengingat pangsa pasar impor dari Jepang yang cukup besar yaitu 30 persen, depresiasi rupiah terhadap yen ikut memberikan tekanan yang cukup besar terhadap kenaikan harga dalam negeri dan defisit transaksi berjalan Indonesia. Fenomena overheated di indonesia dapat diilustrasikan akibat kebijakan uang ketat (Tight Money Policy/TMP) pada awal tahun 1994, awal pemerintahan kabinet VI. 


\section{Kesimpulan}

Dalam tulisan ini arah-arah pokok kebijakan makro dan program untuk mengatasi kondisi ekonomi yang overheating pada tahun-tahun mendatang, masih diperlukan kebijakan makro ekonomi yang hati-hati terutama di dalam era globalisasi (Asean Free Trade 2003, APEC 2008, dan Liberalisasi Perdagangan WTO tahun 2020), yaitu :

a) Kebijakan menjaga kestabilan dan kemampuan ekonomi makro.

b) Kebijakan campuran fiskal dan moneter (Policy Mix) yang terkoordinasi secara seimbang, terutama mengawasi perkembangan dana-dana diluar budget (off budgeting). c) Kebijakan moneter yang hati-hati (prudential) serta kerjasama antar pelaku ekonomi.

d) Kebijakan nilai tukar yang realistis untuk mendorong ekspor.

Secara rinci kebijakan ekonomi untuk mengatasi ekonomi yang overheating masih mengacu pada analisis manajemen permintaan agregat. Sedang arah-arah pokok kebijakan masih diperlukan untuk merestrukturisasi perbankan. Dengan memperkuat struktur financial dan menciptakan prinsip kehatihatian untuk menciptakan self regulatory banking, serta upaya berkelanjutan deregulasi di sektor riil, debirokratisasi, desentralisasi, untuk mendorong ekspor dan iklim yang kondusif untuk penawaran modal.

Tabel 1

Laju Pertumbuhan PDRB Rlil dl Beberapa Negara

\begin{tabular}{|l|c|c|c|}
\hline \multicolumn{1}{|c|}{ Negara } & $\mathbf{1 9 9 4}$ & $\mathbf{1 9 9 5}$ & $\mathbf{1 9 9 6}$ \\
\hline Amerika Serikat & 4,1 & 3,0 & 2,6 \\
Jepang & 0,6 & 2,5 & 3,4 \\
Jerman & 2,9 & 2,8 & 3,0 \\
\hline Korea Selatan & 7,6 & 9,4 & 7,5 \\
Hongkong & 5,5 & 5,0 & 5,2 \\
Taiwan & 6,4 & 6,4 & 6,5 \\
Singapura & 10,0 & 8,0 & 7,2 \\
\hline Indonesia & $\mathbf{7 , 3}$ & 7,5 & 7,0 \\
Malaysia & 8,7 & 9,0 & 8,0 \\
Thailand & 8,4 & 8,6 & 8,5 \\
Filipina & 4,5 & 5,5 & 6,0 \\
Vietnam & 15,0 & 9,0 & 3,8 \\
\hline Cina & 11,8 & 10,0 & 9,0 \\
India & 5,4 & 5,7 & 9,0 \\
\hline
\end{tabular}

Keterangan :

Sumber:

a) Angka Perkiraan

b) Hingga November

- IMF, World Economic Report

: ADB, The Asian Wall Street Joumal

- Bank of America, Country Outhook

- Merryll Linc, Asian Economic Commertary

- Bank Indonesia, Statistik Ekonomi - Keuangan Indonesia 
Tabel 2

Uang Beredar dan Faktor-faktor yang Mempengaruhi (Trilliun Ruplah)

\begin{tabular}{|c|c|c|c|}
\hline \multirow[b]{2}{*}{ RINCIAN } & $1994 / 95$ & $1995 / 96$ & \multirow{2}{*}{$\begin{array}{c}\text { 1995/96 } \\
\begin{array}{c}\text { Posisi } \\
\text { Akhir Poriode }\end{array}\end{array}$} \\
\hline & \multicolumn{2}{|c|}{ PERUBAHAN } & \\
\hline M1 & 7,0 & 8,3 & 53,1 \\
\hline Uang Kartal & 3,6 & 2,2 & 21,1 \\
\hline Uang Giral & 3,4 & 6,1 & 32,0 \\
\hline Uang Kuasi & 25,9 & 42,5 & 179,3 \\
\hline Deposito \& Tabungan (RP) & 20,0 & 34,7 & 137,8 \\
\hline Deposito Valuta Asing & 5.9 & 7.8 & 41.5 \\
\hline M2 & 32,9 & 50,8 & 232,5 \\
\hline Faktor-faktor yang mempengaruhi M2 & & & \\
\hline Aktiva Luar Negeri Bersih & $-4,1$ & 9,1 & 35,2 \\
\hline Bank Indonesia & $-2,0$ & 10,3 & 47,2 \\
\hline Bank-bank Umum & $-2,1$ & $-2,1$ & $-12,0$ \\
\hline Tagihan Kepada Pemerintah & $-2,7$ & $-5,2$ & 24,7 \\
\hline Tagihan Pada Soktor Usaha & 39,4 & 46,9 & 265,1 \\
\hline Tagihan Kepada Lembaga dan Perusahaan Pemerintah & 0,8 & 1,6 & 11,2 \\
\hline Tagihan Kepada Periusahaan Swasta dan Perorangan & 38,6 & 45,3 & 253,9 \\
\hline Lainnya & 0,3 & 0,0 & $-43,1$ \\
\hline
\end{tabular}

Sumber : Bank Indonesia, Statistik Keuangan

Tabel 3

Indikator Moneter - Perbankan

Tahun 1995

\begin{tabular}{|l|c|c|c|c|c|c|c|c|}
\hline \multicolumn{1}{|c|}{ Indikator } & Jan & Feb & Maret & April & Mei & Juni & Juli & Agt \\
\hline M2 & 176.2 & 179.8 & 181.7 & 182.7 & 185.2 & 192.1 & 196.8 & 202.1 \\
Uang Kuasai & 131.6 & 132.5 & 136.8 & 138.0 & 140.1 & 154.1 & 149.4 & 153.7 \\
M1 & 44.6 & 47.3 & 44.9 & 44.7 & 45.1 & 47.0 & 47.4 & 48.4 \\
\hline
\end{tabular}

\begin{tabular}{|l|c|r|r|r|}
\hline \multicolumn{1}{|c|}{ Indikator } & 1992 & 1993 & 1994 & $1995^{*}$ \\
\hline Kredit Perbankan & 122.918 & 150.271 & 188.880 & 216.765 \\
Posisi Simpanan & 114.850 & 142.679 & 170.406 & 195.465 \\
Posisi SBl20.559 & 23.433 & 15.052 & 11.383 & 3.842 \\
Posisi SBPU & 2.820 & 1.395 & 2.451 & 7.615 \\
Sertifikat Deposito & 2.178 & 2.391 & & 7.133 \\
\hline
\end{tabular}

Sumber : Bank Indonesia 
Tabel 4

Laju Pertumbuhan Inflasl dl Beberapa Negara

\begin{tabular}{|l|c|c|c|}
\hline \multicolumn{1}{|c|}{ Negara } & 1994 & 1995 & $1996 \mathbf{a}$ \\
\hline Amerika Serikat & 2,6 & 3,1 & 3,4 \\
Jepang & 0,7 & 0,9 & 3,4 \\
Jerman & 3,0 & 2,6 & 2,5 \\
\hline Korea Selatan & 6,4 & 6,0 & 5,0 \\
Hongkong & 8,1 & 9,0 & 8,5 \\
Taiwan & 3,9 & 4,5 & 3,0 \\
Singapura & 3,8 & 3,5 & 2,0 \\
\hline Indonesia & 9,3 & $7,9 b$ & 7,4 \\
Malaysia & 4,2 & 4,5 & 4,0 \\
Thailand & 4,7 & 4,5 & 4,0 \\
Filipina & 9,0 & 8,0 & 8,5 \\
Viatnam & 14,4 & 9,5 & 9,5 \\
\hline Cina & 21,7 & 18,0 & 10,0 \\
India & 10,4 & 8,0 & 9,0 \\
\hline
\end{tabular}

Keterangan :

a) Angka Perkiraan

b) Hingga November

Sumber:

- IMF, World Economic Report

- ADB, The Asian Wall Street Journal

- Bank of America, Country Outlook

- Merryll Linc, Asian Economic Commertary

- Bank Indonesia, Statistik Ekonomi - Keuangan Indonesia

Tabel 5

Neraca Perdagangan Indonesia

Tahun 1990/91 - 1996/97

(Dalam Juta US\$)

\begin{tabular}{|l|l|l|l|l|}
\hline Keterangan & \multicolumn{1}{|l|}{ Ekspor } & Impor & Jasa-jasa & Transk. Berjalan \\
\hline $\mathbf{1 9 9 0 / 9 1}$ & 28.143 & -23.208 & -8.856 & -3.741 \\
$\mathbf{1 9 9 1 / 9 2}$ & 29.714 & -24.803 & -9.263 & -4.352 \\
$\mathbf{1 9 9 2 / 9 3}$ & $\mathbf{3 5 . 3 0 3}$ & -27.317 & -10.547 & -2.561 \\
$\mathbf{1 9 9 3 / 9 4}$ & 36.504 & -29.127 & -10.317 & -2.940 \\
$\mathbf{1 9 9 4 / 9 5}$ & 42.161. & -34.122 & -11.527 & -3.488 \\
$\mathbf{1 9 9 5 / 9 6 ^ { \star }}$ & 46.904 & -41.846 & -13.001 & -7.943 \\
$\mathbf{1 9 9 6 / 9 7 *}^{*}$ & 53.264 & -45.471 & -14.667 & -6.874 \\
\hline
\end{tabular}

Keterangan : Porkiraan Realisasi

** Perkiraan

Sumber : RAPBN 1996/97 


\section{Daftar Pustaka}

Alkadri, 1996, Analisis Perkembangan Ekonomi Makro Indonesia 1995 dan Prospek 1996, Analisis CSIS.

Bahan-bahan Diskusi Kelas Matakuliah Lingkungan Ekonomi, 1996, Program Magister Manajemen, Angkatan XIll, Universitas Gadjah Mada.

Boediono, 1995, Ekonomi Makro, BPFEUGM, Yogyakarta.
Harun, Muchlis, 1996, RAPBN 1996/97 dan Pengaruhnya Terhadap Perkembangan Dunia Usaha, Bank dan Manajemen.

Prasetiantono, A. Tony, 1990, Antologi Ekonomi Indonesia, Edisi Pertama, BPFE, Yogyakarta.

Samuelson, Paul A, 1995, Economics, International Edition, Fifteenth Edition, McGraw-Hill, Inc. 